\title{
A Brief Account Of Mohtarma Fatima Jinnah's Political Struggle And Service For Restoration Of Democracy In Pakistan
}

\author{
Summer Sultana \\ Department of Political Science \\ University of Karachi
}

\begin{abstract}
Through her political struggle in favour of the nation of Pakistan, Mohtarma Fatima Jinnah set such an example of struggle, courage and sacrifice that bears a significant place in our political history. Using her talents and outstanding courage and spirit she not only trembled the strong quarters of the rulers but also emancipated the nation from the grasp of fears they faced at the hands of these rulers. Her life-long struggle continued for the progress and development of the country and nation. She had the courage and character to criticize the huge figures in the power when she noticed any intrigue and evil designs being fabricated against the country and nation.
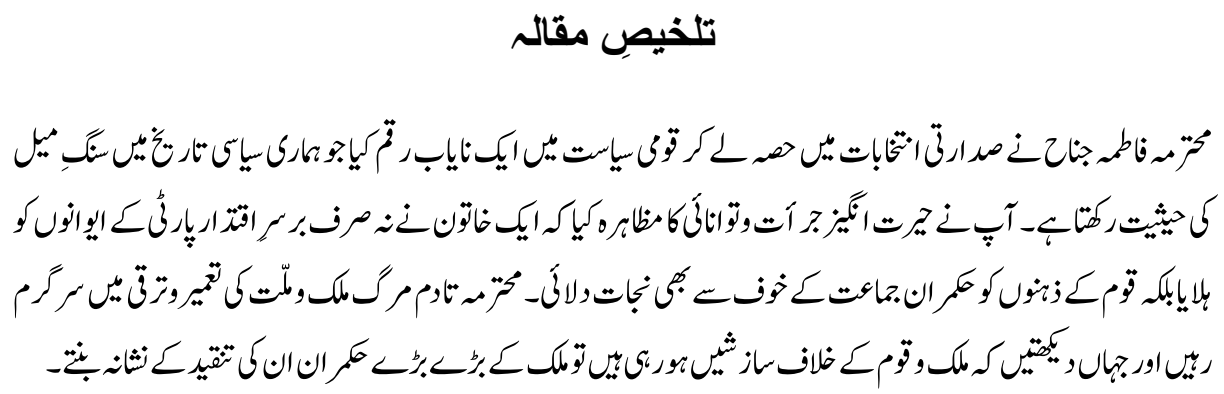

Fatima Jinnah Entry in Country's Politics as Presidential Candidate

After death of her brother Quaid-e-Azam Muhammad Ali Jinnah, the first lady of Pakistan, Fatima Jinnah devoted herself for the social service of the nation. When General Ayub Khan announced the presidential elections, the COP - a political alliance of five political parties - approached her with the request to contest this election. By that time, aged 71 years, Fatima Jinnah was dissociated with politics, and hence she regretted to accede to this request. However, on the persistent persuasion of the political leaders and for deep affection and willingness of the people, she agreed to contest the election with the aim to terminate dictatorship from the country and for the betterment and development of the country and nation by way of bringing about a democratic system of politics. At a time when even big shots in the politics had not the slightest courage to criticize or confront the dictatorship of Ayub Khan, this old lady proved so courageous that the entire public from Khyber to Dacca and from Karachi to Chittagong stood in 
favour of Fatima Jinnah. This election was the first occasion after Pakistan came into existence, because such enthusiastic exhibition of processions and meetings was not seen in the previous elections in entire Pakistan i.e. in the eastern and western wings.

\section{Fatima Jinnah's Popularity}

"A huge crowd of people had appeared to have a look at this great leader during her journey from Peshawar to Rawalpindi in October 1964. Her popularity can be imagined by the fact that by this time she had not even formally announced her support for the Council Muslim League that opposed the then government. The crowd was so large and dense that the distance of merely 6 miles from the city to Deans Hotel could be covered by her motor car in two hours. The scenes of her reception reminded the popularity of her late brother Muhammad Ali Jinnah. All the streets and balconies of houses throughout her way were covered with people. Decorations and welcome banners at Piro-Dhai, Pabbi and Nasrpur - places located on the Attock Highway - exhibited how much the common people respected and loved this great leader." (Talboot, 2004) About her decision of contesting the election, she had herself claimed that "I decided to context the election of President at the call by the nation." (Chiragh, 2001, p. 401) "Miss Fatima Jinnah had graciously accepted their request for nomination as a candidate for the presidential elections." (Daily Dawn, 1964)

\section{Fatima Jinnah Versus Ayub Khan}

Miss Fatima Jinnah's status and place was far higher than that of Ayub Khan. People respected her from the cores of their hearts. On official and private levels, she was requested several times to withdraw from the election contest because it was feared that the member of the Basic Democrat, who had the right to vote and who were used as puppets by President Ayub Khan, would favour Ayub alone, and she would become a victim at the hands of the greedy politicians. Even the opponent contestant for Presidential candidature, Gen. Ayub Khan himself was convinced of Fatima Jinnah's honour and prestige. "In a public speech on October 16, 1964, he said that he had deep respect for Miss Fatima Jinnah and that he also admitted the fact that whatever she realized and felt about some reality, she expressed in clear and straight words. He further said that Fatima Jinnah's intensions and aims were known to all but her claim that those people for whom and for whose interests she had come out in the field of action, they would even after (the elections) would retain regard for her status and place, seemed impossible. The reason for this impossibility was, according to Ayub Khan, that those people had various facets and they were bring Fatima Jinnah to the forefront of elections only for their own vested interests and greed of power. These people, he said, had started taking benefits using her name. He asked whether it was fair that Fatima Jinnah's name should be used merely for the greed of power, and as to why she was bring troubled to 
visit and make speeches in streets and bazaars at that old age. Ayub Khan warned that after the elections (if Miss Fatima won), these selfish people would be maddened by the power and hence they would keep no more regard for any one's personality or honour" (Chiragh, 2001, p.402).

\section{Fatima Jinnah's 9-Point Manifesto}

Despite various tricks and designs of Ayub Khan to abstain her from contesting the elections, Fatima Jinnah, regardless of her old age, made strenuous efforts and gave the ruling group a really hard time. For her presidential manifesto she offered a 9-point program, the summary of which is as follows:

1. "A democratic system in harmony with the freedom, security, unity and the basic ideology of Pakistan will be set up in the country.

2. Pakistan will be made such a welfare state where every citizen will have facilities of life.

3. Class distinction will be removed from the society, and there will be equal rights and privileges for the minorities.

4. People will be provided relief in taxes.

5. Preventive measure against floods will be taken in East Pakistan.

6. Water-logging and salinity will be controlled in West Pakistan.

7. Living standard will be raised by checking the undue increase in population.

8. Misappropriations and crimes will be dispensed with in every department of the administration.

9. The people of Jammu and Kashmir will be supported in their struggle for the right of self determination." (Chiragh, 2001, p.402)

Huge crowds of peoples were seen in the processions and meetings of Ms Fatima Jinnah during her election campaign. She strongly criticized the dictatorship of Ayub Khan. She raised the slogan "Democracy versus Dictatorship". "One of her journey by train, during the campaign, from Dacca to Chittagong (a distance of 200 miles) could be covered in 28 hours." (Talboot, 2004, p.249) In deed she won exemplary support and popularity throughout the country. Her election campaign had out of a sudden developed such enthusiasm and excitement, effect of which, disregard of its immediate impact, were of great consequence in the long run.

\section{Public Support and Leaders Role}

However, despite demonstrations of all the popular support and her honors like the first lady and the Mother of the Nation, it was hard for the religious leaders to accept her as 
head of the state, just because she was a woman. Maulana Maudoodi and the Jama'at-eIslami did support Fatima Jinnah like the top leaders of Deoband school of thought, but most of the religious leaders from the Brelvi school of thought opted to support Ayub Khan. Several Sajjada Nasheens like Pir of Dewal Sharif also supported General Ayub Khan. President Ayub Khan in his monthly speech on $1^{\text {st }}$ January, 1965 said:

"This Presidential election is not between two persons but it is the matter of selection of one of the two systems. Both these systems with their outline are before you. Now it is up to you which one of these systems you accept and which one you opt to reject" (Chiragh, 2001, p.403).

The public and the voters viewed both the contesting personalities and compared them. They could see leadership qualities in Fatima Jinnah but they were unable to give her their votes directly because the right of vote was vested in the 80,000 Basic Democracies members (BD Members) who could be easily controlled by the government. At this moment, the patriot Pakistanis were of the view that if Ayub Khan loved Pakistan, then he should withdraw from the presidential election in favour of Miss Fatima Jinnah.

\section{Services for Restoration of Democracy}

The military dictator Gen. Ayub Khan decided to contest the presidential elections in 1964. In order to defeat Ayub Khan, a united platform in the name of 'Muttahida Mahaze-Amal' was form which comprises Maulana Abul Ala Maudoodi of Jamat-e-Islami, Wali Khan of National Awami Party (NAP), Sheikh Mujibur Rehman of Awami League, Khawja Nazimuddin of Bhashani's Council Muslim League and Chaudhary Muhammad Ali of Nizam-e-Islam Party. These gentlemen in the form of a group went to Mohtarma Fatima Jinnah with the suggestion that she should contest the election against Ayub Khan. Fed up of political intrigues and intricacies, Mohtarma Fatima Jinnah, aged above seventy years, was living an isolated life. In view of her health and old age she expressed her inability to accept the offer. However, on emphatic persuasion by the political leaders to mobilize in the interest of nation and country, and also at the strong will of the people, she change her mind and gave consent for the contest. This meant that a woman could be the future President. To utter disappointment of Ayub Khan, the entire nation from Karachi to Chittagong and Khyber to Dhaka stood behind this brave lady. "General Ayub Khan could not even imagine that an old and weak lady like Fatima Jinnah would show the courage to confront him in the elections" (Muneer, 1993, p.18). During the election campaign, she strongly criticized martial law and military dictatorship as she was convinced that these two elements were detrimental to democracy. She believed that it was the people of Pakistan who had the right to rule through democracy. Fatima Jinnah had raised her voice for the people of Pakistan when even strong and toll figured men did 
not have the courage to do so. They had rather played their role in keeping the women away from politics and legislative institutions.

The election campaign of Miss Jinnah was marked with her memorable public meetings and processions from West Pakistan to East Pakistan. These processions were attended by large number of people coming from far and wide to see and listen to her. The high strength of people attending her processions and addresses was a proof of their love and affection for her as well as expression of hatred and condemnation of the dictatorship. They also believed that Miss Fatima could restore democracy and hence bring prosperity in the country.

"It is a fact that if the presidential elections had been held on the basis of adult franchise and one-person-one-vote basis, Miss Fatimah would have surely stood victorious. However, a strange method was applied which could ensure rigging more than any other method" (Muneer, 1993, p.12). According to the prevalent system of Basic Democracies (BDs), only 80,000 B.D. members from both the wings of the country were eligible to cast their votes. It was surprising that instead of a population of about 100 million people; only 80,000 individuals were allowed to vote. This already tilted the balance in favour of Ayub Khan.

"The task of restoration of democracy was undertaken by a courageous and brave lady who was firmly determined to restore democracy. Large crowds of people would come to her processions to listen to her articulate and eloquent speeches. Despite her old age, her voice sounded very graceful and dashing" (Nawab, 2003, p.29). She was to contest a strong military dictator who was the framer of the Constitution under which presidential elections were to be held. Under the Basic Democracies system, the 80,000 members were to vote in fact for themselves. Despite all this, Miss Fatima Jinnah was determined to crash the thought that Ayub Khan was undefeatable. Fearful of the increased popularity of Miss Jinnah among the people, Ayub Khan tried hard to make her withdraw from the elections or she could be constitutionally declared ineligible for the election. She was pressurized and threatened not to contest the elections. Her party workers and the students engaged in her election campaign were detained. The religious leaders were prompted by the government to declare that from Islamic legal point of view, a woman could not head a state. At this point, Maulana Maudoodi issued a decision (legal verdict) that disregard of that any other woman was eligible to head any other state, at least in Pakistan the Mother of the Nation i.e. Miss Fatima Jinnah was eligible to become head of the country. "Ayub was persuaded by his party to use the religious card against Miss Jinnah. A 'fatwa' (religious decree) was obtained from some ulema to the effect that a woman could not become the head of a Muslim State. The opposition organised an even larger set of ulema to produce an equally authoritative 'fatwa' in support of Miss Jinnah. They discovered from the writings of various Muslim jurists that a woman could become 
the ruler under exceptional circumstances. And who could deny, asked the opposition, that Pakistan was going through exceptional circumstances? The weapon of religious decrees worked against Ayub throughout the campaign" (Gohar, 1994, p. 278-279). "There were a number of political intrigues and unfair means and condemnable tools used to let Miss Jinnah down, yet she bravely confronted these evil designs. Jails were packed with her party workers at which she strongly protested. The strike in the end of 29 September 1964 proved a big blow for the government" (Khan, 2002, p. 147)

In her person, Miss Fatima Jinnah was of very firm and great character, principles and sincere. She had devoted all her talent, intelligence and competencies for the constructive work, and despite being a benefactress of the people of Pakistan, she had to fight against the evil minds. She was greatly motivated to serve her nation using all her wisdom, knowledge, courage and merits of character. "In her public address in Multan in December 1964 she frankly narrated that:

"Some workers came to me some time ago and told that the nation is awaiting me and is willing that I should come into the field of action to stand by them. As my nation needs me, I have stepped into the field and am bearing for the sake of my nation every suffering. I am taking up tiring journey for my people whose betterment and prosperity is my mission. I need neither wealth nor any high position. I am come with a conception, with the slogan of restoration of democracy. I want to see such democracy where it is the people who make decisions; where people participate in all functions of government. So, the public will should be respected. They should not be forcibly rules." (Rehman, 2003)

Apparently that was not true but with one statement she demolished the temple of personality worship cult and raised he minaret of peoples' voice in support of democracy. Her symbol in the elections of 1965 was 'lantern' - the source of light - indigenous and known to every Pakistani, she came forth as source of light when the alleys of Pakistani politics were darkened by the huffing and puffing of the dictator and his legates. She will be remembered as the first and the foremost defender of democracy and if the polls would not have been rigged, no one could have stopped her from coming to power not like other presidents but as a repository of the hopes and aspirations of the peoples of Pakistan. "Miss Jinnah was seen as the only hope of changing an unjust and oppressive system. The crowds that greeted her in East Pakistan were even larger than those in West Pakistan. In her speeches Miss Jinnah criticised Ayub mercilessly, portraying him as an interloper and a dictator, and alleging that his ministers and governors were his lackeys who had no real power. She attacked Ayub and his family for corruption. One minister whom she signled out for personal condemnation was Bhutto. She called him an "inebriate and a philanderer" in a speech in Hyderabad. Ayub could take it no more and, 
at a press conference in Lahore, he asid that Miss Jinnah had been leading an "unnatural" life, a reference to her spinster hood, and was surrounded by "perverts" Everyone in the Government was totally stunned, but somehow Ayub survived, mainly because the campaign rhetoric had already sunk to a low level and rival parties were freely exchanging invective and abuse. The campaign raised serious questions about Ayub's style of government. Allegations of corruption against Ayub's family, particularly his son Gohar Ayub, were openly levelled and widely believed" (Gohar, 1994, p. 277-278).

In an environment where brave men were scarcely seen, the courage and determination of Miss Jinnah was exemplary. Despite her poor health and old age, she took an active part in the election campaign. In her addresses she pledged to introduce the concepts of transparent democracy, social justice and fairness, social parity and knowledge and creative freedom.

The results of the presidential elections were mainly the same as they expected. Ayub Khan was aided by the official machinery, big business shots and land owners. The press was, as usual, exaggerating the feats of the government while ignoring the political activities of Miss Fatima Jinnah. "After the elections in the West Pakistan (on October 31, 1964) and in East Pakistan (on November 10. 2010), results of the elections were declared by Mr. G. Moeenuddin, the Election Commissioner. The results revealed the following position:

Results of the 1964 Presidential Elections

\begin{tabular}{|l|c|c|c|c|}
\hline Candidate & $\begin{array}{c}\text { West } \\
\text { Pakistan }\end{array}$ & $\begin{array}{c}\text { East } \\
\text { Pakistan }\end{array}$ & $\begin{array}{c}\text { Total } \\
\text { Votes }\end{array}$ & $\begin{array}{c}\text { Percentage of } \\
\text { Votes }\end{array}$ \\
\hline Ayub Khan & 28,939 & 21,012 & 49,951 & $63.31 \%$ \\
\hline Fatima Jinnah & 10,257 & 18,434 & 29,691 & $36.60 \%$ \\
\hline K.M.Kamal & 90 & 83 & 183 & ---- \\
\hline Mian Bashir Ahmed & 54 & 11 & 65 & ---- \\
\hline
\end{tabular}

Source: Constitution of Pakistan, 1973, p. 86

The results clearly showed that Miss Jinnah would have certainly stood victorious if the elections had been fair because the degree of her popularity in both wings of the country was on a very high side. Even an indirect fair election would lead her to triumph. As for victory of Ayub Khan, it owed to his military strength and her self-designed system of elections. The thousands of B.D. members who voted for Miss Fatima Jinnah in such tense situation, had in fact done so at the risk of their life and interests. Although Fatima Jinnah could not win the elections, yet the number of votes she acquired was sufficient to crack the iron edifice of Ayub Khan, the dictator. It was the first time that elections were marked with dishonesty and rigging for the sake of power. This evil was exercised as a principle. Pakistan Movement went successful due to combined efforts of men and 
women, yet discrimination was observed in the politics in these elections. It may be mentioned that Miss Jinnah was the only leader those days who was equally popular in West Pakistan and East Pakistan whereas popularity of other leaders was disputed. Despite the results of the elections, Miss Fatima Jinnah's contest helped keep the spirit of democracy alive. She lighted the candle of hope for the nation and for the restoration of democracy.

Miss Fatima's terms with country's rulers always remained tense because she was a straightforward lady who would never compromise over truth and the right. During and after the election campaign of 1964 she was alleged by Ayub Khan for her inappropriateness for candidature, was also criticized for her political ambition. "In response to these allegations she made it clear that she was sister of Quaid-e-Azam who possessed a free thought and acted with the freedom of his conscience and no one had the courage to bring him to a compromise over his principles. Like her brother, she vowed, she would not bow her head before the dictators or the wrong" (Buksh, 2003).

Besides leading her nation, Miss Jinnah had especially headed the women's movement. Her wisdom was visible at each platform she worked at different times. She was in fact a role model for the women of Pakistan. "When Pakistan came into existence, she was honored with the title of 'Lady of Pakistan' (Khatoon-e-Pakistan). Later, when she contested Ayub Khan in the presidential elections, the nation preferred to entitled her as 'Mother of the Nation' (Madar-e-Millat)" (Buksh, 2003). Although she lost in the elections, yet her enthusiasm and passion for the restoration of democracy in Pakistan remained alive. She set an example, before the people, of courage and straightforwardness on one hand, and on the other, she struggled to remind the rulers of the consequences of their deeds. Her strong opposition was supportive in the growth of democracy.

Miss Fatima Jinnah raised voice once again, "in her last message on the eve of Eid ul Azha in April 1967, in support of people's demands about an independence parliament, free press and independent judiciary. She urged upon the people to continue their struggle till achievement of these objectives" (Siddique \& Rizvi, 2003). Her messages for the nation were of great value as, on one hand, the government would keep rectifying its errors and, on the other, the people continued their strife for restoration of their rights.

\section{Symbol of Democracy}

Miss Fatima Jinnah was a very courageous and fearless woman. She proved her courage by her firm stand against President Ayub Khan. Her speeches were always full of excitement. "She had the honor of being the first 'first lady' of Pakistan, and she was given by the nation the tile of 'Mother of the Nation' (Madar-e-Millat)" (Mehmood, 
2008). She was among such great persons who will be remembers for long time for their outstanding abilities. The people of Pakistan still remember her spirits of fearlessness, sincerity and selflessness. She had the same sympathy for the Muslim as did her brother Quaid-e-Azam have, and for this quality Quaid-e-Azam was pride of her sister.

"Mohtarma Fatima Jinnah had, always adhered unflinchingly to the principled stand of the Quaid. She was endowed with the courage of conviction and all the requisite qualities to sustain that courage even in moments of trial and tribulations. But it was only after the Quaid's departure from our midst that these qualities of hers caught the public eye" (Daily Dawn, 1979).

It was unfortunate that for the sake of their vested interests, the opposition party, using all their tools and means in favor of the then government of Ayub Khan, even started disinformation against Miss Fatima Jinnah and referred her to be a psychic patient who allegedly used to be detained at home by Quaid-e-Azam. Miss Fatima Jinnah tolerated bravely all such propaganda and stood firm on her standpoint. Her decision of contesting the elections started changing the political scenario of the country, and fear of dictatorship started diminishing in the hearts of the people. Now they started active participation in the processions and meetings of Fatima Jinnah, their future democratic leader. This lady had reminded people of their Quaid-e-Azam who had taken in his life a solid stand for the sake of democracy and justice. After Mr. Jinnah, Miss Fatima Jinnah was the only leader of his calibre.

As foreseen, the unprecedented rigging, threats, use of government sources and finances by the Ayub government, Fatima Jinnah lost the election which she had morally won. Ayub Khan, the winner of the election had morally been defeated and lost confidence of the common people. Although Fatima Jinnah participated in no other political activity than the presidential election, yet she continued her leadership for the national service. On every important occasion, she addressed the nation or communicated her message. This was such a great deed that no other leader has ever followed.

\section{Miss Fatima Lights the Candle of Hope}

The significant features of Miss Fatima Jinnah's personality were her truthfulness, chastity of character, her principles and her inner sincerity. Her intellect was devoted for the constructive works, but this benefactress of the nation still had to confront evil minded people. Her role is indicative of those ladies who were filled with the passion to serve their country, possessed knowledge and intellect, were truthful and hardworking and were symbols of courage and great character. As representative of the nation she challenged the strong military dictator, held the emblem of her brother's Muslim League, and criticized aloud the dictatorship. It was very difficult for her to win the presidential 
elections because the 80,000 BD members were not to vote the President but they voted for themselves in a system fabricated by the President himself. Having knowledge of all this, she still challenged Ayub Khan as she intended to crash the idea of his being undefeatable. In the elections, against expectations, thousands of BD members had voted for her at the risk of their lives and interests. Although she could not win the elections, yet she was happy and satisfied because those who had won the elections, were still disappointed as Fatima Jinnah had cracked the concrete premises of their power. This election proved the last one for Ayub Khan. Events like the 1965 war against India, his separation with Bhutto in 1966, formation of the PPP in 1967 and the anti-Ayub Khan movement in 1968 forced Ayub Khan to surrender the power. While quitting the power, he committed yet another violation of the Constitution when instead of handing over the government to the Speaker of the National Assembly, he shifted the power to another military dictator General Yahya Khan who suspended the 1962 Constitution and imposed martial law in the country. Although Fatima Jinnah was not living at that time to see all this, but she during the last months of her life she had lighted the fresh obsession of democracy in the heart of the nation.

\section{Overview}

Memory of the Mother of the Nation (Madar-e-Millat) remains alive and fresh in our hearts for her highly devoted services for democracy in Pakistan. She had firm trust in the democratic process that is why toward the end of the year 1964, keeping democratic demands in view, she decided to contest in the presidential elections against General Ayub Khan. Although she might have been certain that she would not succeed in the elections, yet for the sake of Pakistan and the welfare of its people, she participated in the elections and proved herself a tough opponent for the military ruler. Yet, victory in elections was not her aim, rather it was the service for the people and her country that even after elections, she continued her services till her last breath. She was 'Mother of the nation' and we will keep her remembering as 'Madar-e-Millat'.

\section{References}

Buksh, S. (2003) Article on Fatima Jinnah In Magzine Ilim Ki Roshini, Mader-e-Millat No, Allama Iqbal Open University, Islamabad, Vol-5, Add-II, p8.

Chiragh, M.A. (2001) History of Pakistan, Sang-e-Meel Publications, Lahore.

Constitution of Pakistan, 1973, Muhammad Azam Chaudhry, Tahir Sons, Karachi, 1993, p86.

DAWN, 19 September 1964. 
DAWN, 09 July 1979.

Gohar, A. (1994) Ayub Khan Pakistan's First Military Ruler, Sang-e-Meel Publications, Lahore.

Khan, A.S. (2002) Amma Hawa se Amma Councellor Tak, Ilm-o-Irfan Publications, Lahore.

Mehmood, S.Q. (2008) Encyclopaedia, Pakistanica, Al Faisal Nasheran-o-Tajran Kutub, Lahore, p707.

Muneer, A. (1993) Mader-e-Millat Ka Jamhuri Safar, (words of Nawabzada Nusrullah Khan, Lahore.

Nawab, A.A. (2003) 100 Namwar Pakistani, Nawab Sons Publications, Rawalpindi.

Rehman, M. (2003) Article on Fatima Jinnah's Personality In Magzine Ilim Ki Roshini, Mader-e-Millat No, Allama Iqbal Open University, Islamabad, Vol-5, Add-II, p84.

Siddiqui, F.K \& Rizvi, S.S.B (2003) Article on Political Services of Madr-e-Millat In Magzine Ilim Ki Roshini, Mader-e-Millat No, Allama Iqbal Open University, Islamabad, Vol-5, Add-II, p70.

Talboot, I. (2004) History of Pakistan, (Translated by Tahir Mansoor), Tahkliqat Publications, Lahore, p248, 249.

Dr. Summer Sultana is Assistant Professor in the Department of Political Science, University of Karachi. 